Article

\title{
Gender Construction in Experiment-Based Biology Lessons
}

\author{
Kira Kokott ${ }^{1}$, Diana Lengersdorf ${ }^{2}$ and Kirsten Schlüter ${ }^{1, *}$ (i) \\ 1 Institute of Biology Education, University of Cologne, Herbert-Lewin-Str. 2, 50931 Cologne, Germany; \\ kira.kokott@uni-koeln.de \\ 2 Faculty of Sociology, Bielefeld University, Universitätsstr. 25, 33615 Bielefeld, Germany; \\ diana.lengersdorf@uni-bielefeld.de \\ * Correspondence: kirsten.schlueter@uni-koeln.de; Tel.: +49-221-470-1894
}

Received: 30 June 2018; Accepted: 6 August 2018; Published: 7 August 2018

\begin{abstract}
Experimental investigations are an integral part of biology education because they demonstrate essential methods of obtaining knowledge in the natural sciences and generate high levels of learning activity. However, gender differences can arise during experimentation just as in other teaching situations. This article shows examples of social gender construction that may occur in experimental work. To this end, experimental group work was recorded on video and was assessed by the method of film image sequence analysis. The video segments revealed clearly distinguishable behavioral patterns used by the students to establish an identification as a girl or boy. For example, gender-related differences referred to preferring household appliances (girls) or technical instruments (boys) when experimenting, and acting in an attentive (girls) or attention seeking way (boys) during group work. The disadvantage of these patterns is that they may restrict the unfettered development of the personality and, among other things, make it difficult for girls to feel competitive in experimental sciences. In order to balance the situation, teachers must be able to notice these patterns and must know about strategies to broaden students' behavioral range. Concrete proposals for such strategies being applicable in biology lessons but also in other subjects are given in the discussion of this article.
\end{abstract}

Keywords: gender construction; biology education; inquiry; experiments; video study; film image sequence analysis

\section{Introduction}

Applying experimental investigation methods is a central component of inquiry-based learning in science education in order to search for empirical evidence when responding to a research question [1-3]. The same is valid for biology education when looking separately at this special subject of science education [4]. While in former times cookbook-like actions were used, nowadays inquiry-based teaching is the recommended procedure $[5,6]$. This method leaves students more freedom to autonomously plan and conduct their investigations in a reasoned way than traditional teaching [7], even if there is a vast variety of approaches of how to put inquiry teaching into practice [8,9]. By getting involved in inquiry-based activities, students shall gain insights into how research works and ideally may get interested in this creative, but also structured and well-grounded process. The importance of this teaching method is also documented by the fact that it is applied or at least considered as essential in many countries $[10,11]$. From a gender perspective, inquiry-based learning can be seen as an attractive teaching method for both sexes because girls as well as boys prefer doing their own experiments $[12,13]$. In addition, girls prefer to work in an interactional social context [14], which is often realized by working in teams during inquiry-based learning. Thus, inquiry-based learning should be a teaching situation 
which meets the interests of girls and boys on the one hand, but on the other hand might not be as easily handled by girls in comparison to boys because girls reported to have less extracurricular experiences than boys in diverse scientific areas, especially referring to electricity and mechanics [15]. In order to create a level playing field for both sexes, the science subject of biology can be considered as a good starting point for getting involved in inquiry tasks. The reason for this is that contents referring to health and nature are highly attractive to girls, but are still of a certain interest to boys $[14,16,17]$. In addition, one can expect girls to feel better and more competent in biology than in other sciences, because biology is the only subject of the natural sciences which is studied by more girls than boys [18]. Biology, therefore, is an appropriate subject to study students' behavior with respect to gender-related differences because it provides a kind of neutral environment giving both sexes similar chances to participate in solving the assigned experimental tasks.

\subsection{Definition of Gender}

In survey- and theoretical articles it was criticized that the term gender had been used in inconsistent ways and often was misinterpreted as a synonym to the term sex [19-21]. Therefore, it was demanded that the term gender has to be clarified in publications dealing with it $[19,20]$. In our paper, we refer to the definitions developed by West \& Zimmermann [22]. Sex means the biological birth sex, which is determined on the basis of socially agreed biological criteria. Sex category means the social assignment to one sex. This assignment is made by the individual itself but also by its environment. The sex category can be derived from the outer appearance of the individual and involves assessment criteria like one's figure, clothes, hairstyle, presence of facial hair, tone of voice etc. [22]. This sex category is not necessarily the same as the biological sex. Gender denotes adequate behavior in keeping with the chosen sex category. In our study, we analyze students' shown behavior and interpret it in accordance with current social norms of femininity and masculinity in order to uncover how students underline their own sex category. However, our goal is not to stabilize this behavior, but on the contrary, to sensitize teachers that this behavior reflects just the current social norms and may not always be in accordance with the wide variety of a person's individual norms. In a society where tolerance, respect and personal fulfilment are of high value, gender-conform behavior cannot be the measure for evaluating a person.

Sabbe and Aelterman [23] distinguish between different theoretical approaches to define gender. They contrast the essentialist perspectives with the constructionist perspectives. The essentialist perspectives had developed from biological to socialization approaches with the former considering different social behaviors of men and women to be innate while the latter attribute behavioral differences between the sexes to different role expectations of the respective society. However, the essentialist perspectives are considered to still be too deterministic because they emphasize continuity and stability of a person's characteristics and deny a free choice to enact one's own gender role [23]. In contrast, constructionist perspectives are less deterministic. They imply that individuals of a certain sex would not behave uniformly, but their gender performance is shaped by context, space and time [23].

Constructionist perspectives are based, inter alia, on the theory of "doing gender" developed by West \& Zimmermann [22]. It says that gender "is not something we are, but something we do" [24] (p. 106). Gender thereby-in contrast to sex-is not considered as a "... quasi natural starting point ..." [25] (p. 137), but rather as a self-constructed and self-implemented characteristic used and practiced by the individual in interactions with others. Gender identity is thus continuously constructed. "A person does not 'have' a gender until that person has it for others." [25] (p. 138). Gender thus implies the embodiment of psychological, social and cultural characteristics [26]. No rigid patterns apply within the concept of doing gender. It may vary depending on time, interaction partners, and the social environment [24]. Assignment of characteristics is highly flexible, albeit organized in a binary pattern (either the classification "male" or "female" is possible) [25]. This flexibility means, that some characteristics of one gender might occur although the person is generally classified as the opposing gender. Such binary gender classification "errors" are usually ignored by society [25], i.e., a man 
with long hair is not therefore a woman. Such irritations thus do not automatically have the effect of assigning a different sex category. Being aware of this aspect might help students not to stick to gender-conform behavior (that is one does the same what all the others of one's own sex category do) and might help to prevent the development of stereotypes.

It is said that we are living in a "postgender era" now [27]. This means that each individual can freely choose the "range of possible selves" [27] (p. 689). Thus, there should not be any gender constraints forcing an individual to present distinct male or female behavior which might end up in stereotype formation. Instead, an individual should have the chance to freely construct his or her gender, and this construction process always includes the possibility of deconstructing [24] or reconstructing it.

\subsection{Gender Studies in Science Education}

Gender studies in science education have undergone different prioritizations during time and can be grouped in four main categories, according to a comprehensive review of Brotman \& Moore [28]. A first focus was set on documenting gender differences in the classroom pursuing the aim to give girls equal chances to succeed in natural science as boys. By this approach, "deficits" were attributed to the girls and, therefore, girls had to be changed, e.g., by offering them more access to science experiences. In the second, subsequent phase of gender research, the object of change was not so much the girls any longer, but rather the curriculum and the pedagogy in science classes [28]. They should be designed in a way to address the needs and interests of both sexes and not in particular those of the boys. In the third phase, the focal point of change was transferred even further, saying that the nature of science has to be presented in another way so that science is not merely perceived as a male culture, but comprises also female characteristics and by this, will be more interesting to girls [28]. The fourth phase focused on identity [28]. Attention was paid to the fact that girls and boys cannot be considered and treated as a homogenous group. There are differences which have to be taken into account because otherwise, one will not satisfy the requirements of the diverse students, but will end up in developing stereotypes. In addition, gender is just one variable influencing students' attitudes and achievements, because it interacts with other variables like class and ethnicity $[27,29]$. These interactions have to be considered when thinking of suitable support measures for each student. Looking at the present study, at first glance it seems to refer to the first category of gender studies documenting differences between boys and girls. However, these differences are analyzed from another perspective. The question of interest is, in which ways do girls and boys construct their gender, meaning that they-no matter whether consciously or unconsciously-emphasize their femininity or masculinity and by this traditional way of acting, might consolidate existing stereotypic gender expectations.

For getting closer to a gender-sensitive education, three different types of strategies have been suggested according to Kenway \& Gough [30]. These strategies refer either to altering girls' attitudes and aptitudes concerning science or changing the curriculum, or the learning environment. For the latter it was considered to be necessary to re-educate the teachers by changing their attitudes and raising their awareness concerning gender issues and to assist them in developing gender-sensitive teaching methods. Lessons are assumed to be more advantageous for girls if they contain more "interactive, co-operative, contextual, intuitive, holistic and practical learning, and methods which draw on girls' linguistic and imaginative strengths" [30] (p. 10).

A theoretical framework for closing the gender gap in science education was developed by Sinnes [31]. This framework is based on three distinct views of how boys and girls engage in science and suggests three different teaching approaches corresponding to these views. The first one, the "gender neutral" approach, is based on the perspective that males and females are equally capable in doing science. Therefore, gender neutral education material has to be developed to avoid treating males and females in different ways. The second or "female friendly" approach emphasizes that there is a difference between girls and boys, and therefore girls' special interests and needs should be considered in class. The third or "gender sensitive" approach implies that women (just like men) do not constitute an identical group. Therefore, science education has to acknowledge the variety of interests and needs 
of the individuals in a class and should especially give attention to marginalized groups regardless of their sex. This third approach corresponds to the conclusion (or rather vision) that we are arriving to a "postgender era" [27]. Thus, the last approach should be the aspired goal. However, school reality lags behind this goal because schools still are a source of maintaining sex-based categorization and dualistic gender performance [32].

\subsection{Causes for Stereotype Formation}

Several gender-biased factors were identified in classes, which may facilitate stereotype formation [33]. These factors include the teaching and assessment methods a teacher chooses, which meet more or less the preferences of a certain sex category [34]. In addition, the teachers' attitude to science and their function as a role model can be gender-biased, and the same applies for the selected contexts of a teaching content (e.g., technical vs. health-oriented contexts [35]), and also for the type of language and visuals (e.g., portraying mainly male scientists [36]) being used [33]. Teachers' gender-biased behaviors, however, can also be caused by the students themselves who trigger certain teacher reactions by their behavior. Thus, differences in frequency by which teachers call on male and female students to answer their questions can be traced back on the increased volunteering rates of male students [37]. This result demonstrates that gender-biased situations can also arise from students' behavior. This means that students themselves contribute to a solidification of gender-biased situations. Teachers have to be aware of these interdependencies in order to counteract stereotype formation. However, to be able to do so, teachers have to realize which kinds of students' behavior support stereotype formation-which is the topic this paper refers to. Thereby, we wish to support a gender-sensitive teaching approach which means offering students a bigger behavioral repertoire. However, as a starting point of our analysis, we have to refer to the binary structure of traditional gendered behavior in order to point out the missing behavioral elements teachers should refer to for expanding the range of their students' possible behaviors.

\subsection{Gender Research in Germany}

Academic research on gender commenced in the late 1960s [38] (p. ix). In Germany, where the present study took place, gender research in schooling was addressed later than in other countries, but meanwhile has still existed for more than 30 years [39]. Studies giving an overview of the research scene in German-speaking countries [39-42] distinguish between different directions of research. According to Faulstich-Wieland \& Horstkemper [39], the focus was set either on the learners or the instructors. Regarding learners, gender differences in school success were analyzed, as well as possible causes resulting in the maintenance of gender differences like, for example, curricula, school books, communication and interaction forms. For teachers, the following issues were relevant: Sex ratio of teachers with respect to different types of schools, which raised the problem of a feminization in primary teaching, and possible differences in teaching between male and female instructors.

More recently, research has also been done on the mechanisms by which gender differences are constructed. Faulstich-Wieland \& Horstkemper [39] refer to studies addressing the question of how teachers deal with pupil behavior and in doing so, maintain gender stereotypes. This maintenance and continuation of gender stereotypes as well as the unequal treatment of the two sexes occurs on a regular basis—which was also shown for countries other than Germany, e.g., reference [43]. However, this unequal treatment is not noticed by the ones involved. Even more so, this maintenance of gender stereotyping is being performed under the guise of gender neutrality [44].

\subsection{Aim of the Present Study}

The present paper also addresses the issue of gender differences. The aim is to uncover persistent strategies of gender construction that emphasize binary gender differences during experimental group work in school, more precisely in biology education. Knowing these strategies might help teachers to counteract the solidification of stereotypes. 


\section{Materials and Methods}

\subsection{Sample and Study Design}

At a university in North Rhine-Westphalia (Germany), an inquiry course was offered to pupils in winter semester 2014/15 to encourage skills in experimentation. The participants came together 10 times for $1.5 \mathrm{~h}$ sessions during this semester. The group included 9 boys and 10 girls from the fifth year at an urban Gymnasium (college prep school in an affluent neighborhood). The students were divided into one mixed-sex and three same-sex subgroups (one boy group and two girl groups) of four to six persons. The work on the experimental assignments was done within these subgroups. The composition of the groups remained the same for all 10 sessions, whereby numbers of participants varied slightly due to occasional illness or for other reasons.

The pupils were supervised by candidate teacher students in biology. Various scientific methods embedded in different areas of biology were treated during the course. Emphasis was put on students' independent experimentation as far as possible. Three subgroups (an all-boy group, an all-girl group, and a mixed-sex group) were videotaped separately during the experimental work.

Of the total of 10 experimental assignments that were videotaped, two were used as a basis for the detailed analysis. These two experimental exercises were selected based on the following criteria: Issuing of clear work instructions by the supervising candidate teacher students, low levels of incidents and disruptions caused by outsiders, noticeable/interpretable interactions by male/female pupils, and good acoustic intelligibility of the groups. One experimental assignment referred to different measurement tasks for which students had to choose suitable measurement devices (they could choose from an electronic balance, a measuring cup, a ruler, a tape measure, and a thermometer). The second experimental assignment covered the topic of analyzing various foodstuffs for the presence of different nutrients/nutrient groups. While the first approach corresponded more to an open inquiry process, the second was more similar to a structured version. Separate video material of the experimentation process was available for all sub-groups (boys, girls, mixed-sex group). Thus a total of six videos were included in the evaluation (boys, girls, and mixed-sex group for the two selected experimental assignments). Each video consisted of about 75 min of teaching time comprising a theoretical introductory phase, the inquiry process, and a debriefing. In total, $450 \mathrm{~min}$ of video material were analyzed. In a first step, these videos were divided into thematic sequences. The thematic sequences were then divided into smaller units, that is, thematic subsegments. Film image sequence analysis according to Bohnsack [45] was then applied to these subsegments (see next section) in order to identify gender-typical strategies. An abductive approach was applied to the interpretation. This means that the interpretation was not based on resorting to a given categorical or encoding system but rather on commonly observed societal experiences and explanatory paradigms. The various sequences were then compared based on similarities and differences in order to define categories of gender-typical behaviors. This was always done in consultation with a second observer (a social scientist) to ensure categorical matches and reach agreement on the category system used.

\subsection{Film Image Sequence Analysis According to Bohnsack}

Film image sequence analysis, according to Bohnsack [45,46], is an interpretive method used extensively in the social sciences. To date, it has seen little use in the area of research on biology didactics. The aim of Bohnsack's method is to render explicit the implicit, a theoretical knowledge of actors in an image or video. In other words: The everyday activities of these actors are based on knowledge or stances/attitudes they themselves do not reflect on. The purpose of Bohnsack's analytical method is to gain access to and denominate this self-evident content. The analytical method comprises different interpretive steps, which are outlined below in a simplified form (Figure 1).

The first step is formulative interpretation, followed by reflective interpretation. The formulative interpretation comprises two steps. The first interpretive step (1a) corresponds to the pre-iconographic level, the identification of the visible. The second interpretive step (1b) refers to the iconographic level. 
The aim here is to link the actions identified at the pre-iconographic level with a concept or theme corresponding to generalized knowledge or well-known role patterns in society. In this interpretation, one imputes "in-order-to motives" meaning that a person performs an activity for a special reason. Actions at the pre-iconographic level may only be a gesture. Interpretation of the gesture may then give it a different meaning. [For example: At the pre-iconographic level (1a), the gesture of tipping one's hat is identified. At the iconographic level (1b), the gesture is interpreted as a greeting [46] (p. 77)]. The example is thus tipping the hat with the purpose of greeting ("in-order-to motives").

In interpretation step $1 \mathrm{~b}$ of the given example, the perceived gesture was attributed to an institutionalized meaning, which almost everyone in our society should be familiar with. Because of its general nature, the gesture is separable from the specific video sequence or picture. This is designated as a communicatively generalized meaning. Another example from the video material we analyzed would be as follows: The gesture identified in step 1a "boxing" is interpreted as "exhibitionism" in step $1 b$.

The expressive content of the action or gesture is interpreted in step 2 (reflective/documentary interpretation). In this step, the hidden experiential background of the action or gesture is analyzed. The action itself, thereby, is seen as a document for the experiential background with the latter being neither conscious nor directly intended by the person(s) involved in the action. The experiential background is also known as the documentary or conjunctive knowledge. This knowledge or experience is supra-individual and thus leads to a jointly constructed reality within a society. The example of "tipping one's hat" can be interpreted as courtesy in step 2. Coming back to the above example from our video, the "exhibitionism" can also be interpreted as masculinity. Concerning our study, interpretation step 2 focuses on a single central aspect: the demonstration of masculinity or femininity.

In summary, according to Bohnsack, there are two levels of meaning-the communicatively generalized (iconographic) one and the documentary (iconological) one. When analyzing the video footage, we will make use of communicatively generalized knowledge (interpretation step 1b), which will then be subjected to reflective interpretation (interpretation step 2).

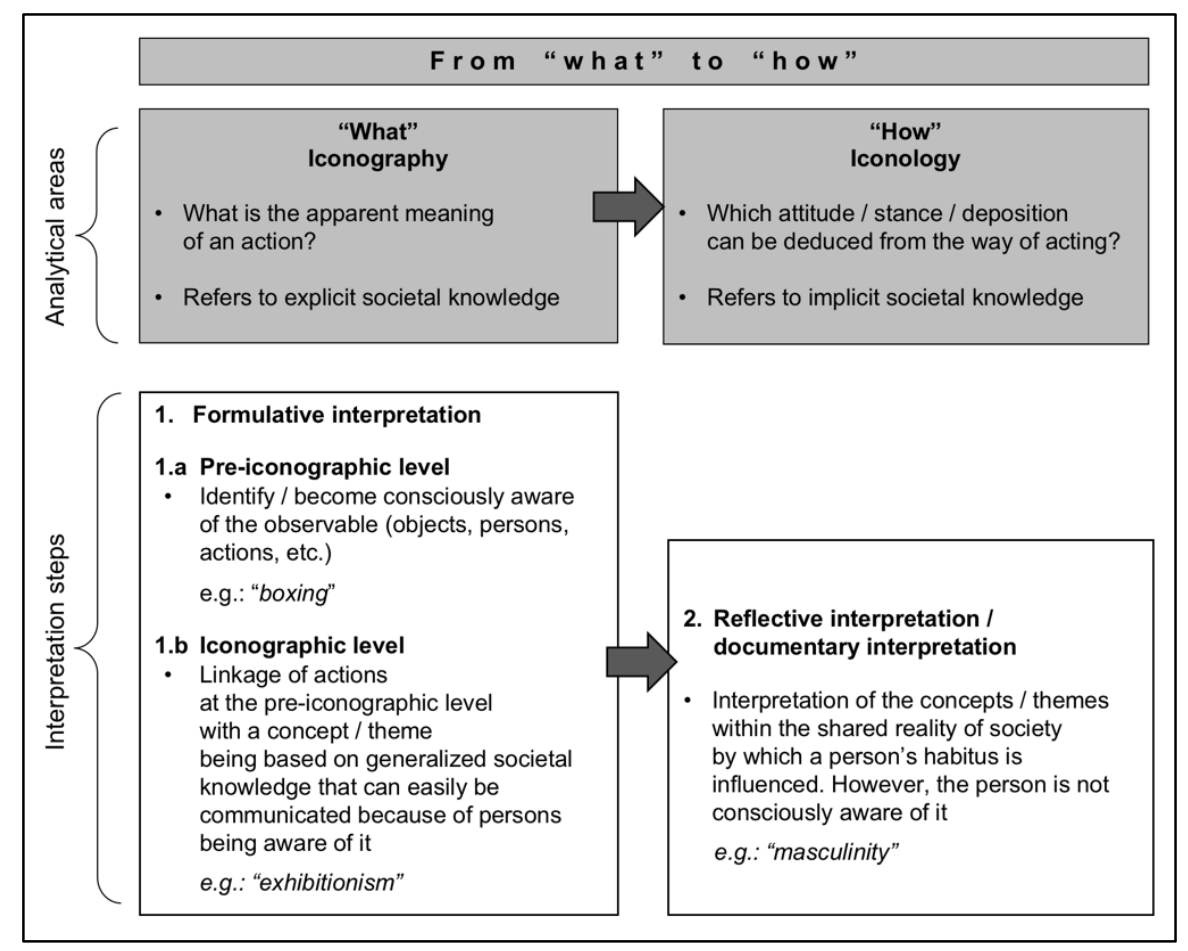

Figure 1. Analytical steps of the documentary method based on R. Bohnsack [45] as applied in the present study. 


\subsection{Critique of Method}

Two unavoidable criticisms related to the analytical method used in the present study are addressed below.

(1) Because of their qualitative orientation, the results of this study cannot be considered to be representative of every student body and every experimental situation. However, the results are significant for the group analyzed and are confirmed by repeated occurrence within the subgroups. In order to make use of this information as a teacher, one must analyze one's own course groups in order to identify gender constructions within them.

(2) The evaluative basis in the video analysis is not objectified knowledge, but rather the analysis resorts to implicit or tacit knowledge [46] (p. 83).

An example from the present study would be the use of household items for purposes of experimentation. Household items have female connotations that are not fixed in writing but which are based on implicit knowledge. An observer noting special male/female pupil behavior is making use of implicit/tacit knowledge about sexes and gender construction, whereupon the behavior is interpreted on this basis in a further step. In this context, the observer's "blind spot" must be emphasized in the analysis according to Bohnsack. By this is meant the "[ . . ] limitations dictated by the observer's or interpreter's own standpoint, the extent to which his or her interpretation is guided unawares by milieu and culture." [46] (p. 87). Only intensive self-reflection or a methodical control measure (e.g., in the form of a second encoding by a gender research expert-as done in this study) can lead to reflection on-or an objective grasp of—one's own milieu and cultural dependence.

\section{Results}

Some recurring patterns can be identified in the analyzed sequences; these are supportive in constructing a female or male gender. These patterns are sometimes used exclusively by boys or girls. Sometimes they simply occur in a higher ratio in one of the sexes. There may be even more behavioral elements of relevance. However, we refer only to those that were apparent and conclusive to the observers.

\subsection{Behavior Patterns Used for the Construction of Female Gender}

An initial behavior pattern to underline a female gender (interpretation step 2) is the use of household items, such as a measuring cup (interpretation step 1a). For determining the amount of water in a bottle, this is a suitable tool (more than a balance or a ruler). However, it is also an instrument commonly found in the kitchen (interpretation step 1b), which can be regarded as a female behavioral field. As Joanne Hoven Stohs [47] wrote, the kitchen serves as a field for representing and demonstrating the female gender. Häussler et al. [48] also described how girls prefer content connected to their life situation-for example the household. The measuring cup thus has a female connotation and can be used as a means to construct femininity (female gender). The clearly contrasting behavior of boys (avoiding the measuring cup and instead reaching for the electric balance) serves to delimit—and thus construct-masculinity.

Another characteristic used to construct female gender (interpretation step 2) is caring behavior (interpretation step 1b). Overall the girls demonstrated caring behavior aimed at caring for the entire group, whether an all-girls group or a mixed group. The caring behavior in the video material viewed included clearing away of materials, laying out of working materials so everyone was able to see them clearly, and mutual offering of help (interpretation step 1a).

A frequent behavior pattern for construction of femininity can be identified as touching one's own hair in various ways (interpretation step 1a). Sometimes the hair is brushed back, and sometimes it is played with. This behavior pattern is practiced by both the female pupils and partially also by the female teacher who accompanied her pupils from the school to the university building where the inquiry course took place. It is thus exemplified by females at different age levels. It can be interpreted 
as primping/preening or as a sign of embarrassment/clinging to oneself/familiarity (interpretation step 1b). However, it must be said that all girls as well as the teacher had long or mid-length hair reaching at least to the chin. Nevertheless, the described behavior was also observed in the latter case. It even occurred when the hair was tied back but there were some loose strands of hair. In contrast, the boys mainly had short haircuts. They seldom touched their hair, and if they did so, it was in another manner, which could partially be interpreted as more vigorous.

\subsection{Behavior Patterns Not Clearly Assigned to a Male or Female Gender Role}

The term "request" (Interpretation step 1a) cannot be clearly assigned to one sex category, although a tendency towards the girls is certainly apparent. Based on the video material viewed, the requests that can be interpreted as "asking for help" (interpretation step 1b) are more likely to characterize a female trait because girls are not afraid to exhibit this behavior. On the other hand, it is noticeable that not all boys make requests. This is done only by boys with good standing within the group as demonstrated by popularity, admiration on the part of other group members, and assumption of the role of group leader. A boy who makes requests or asks for help thus has sufficient social and symbolic capital as a man. According to Bourdieu, symbolic capital can be designated as prestige or a good reputation [49]. Such a boy can make a request without having to fear the ridicule of his classmates.

\subsection{Behavior Patterns Used for Construction of Male Gender}

In boys, the counterpart to reaching for household items as observed in girls would be reaching for the electric balance (interpretation step 1a). In the mixed-sex subgroup, the leader of the boys immediately reaches for the electric balance, and in the boys-only group, a problem actually intended to be solved with the measuring cup is solved with the balance. The boys clearly distance themselves from the female field of activity "kitchen" by their behavior (interpretation step 1b), thereby demonstrating masculinity (interpretation step 2).

Carrying a pen in one's breast pocket (interpretation step 1a) also contributes to the construction of masculinity (interpretation step 2). This behavior is mostly practiced by boys. The only girls who did so were those two in the mixed-sex group. The girls of the girl group did not show this behavior, even though they had the possibility to do so because all pupils wore lab coats with breast pockets. This behavior appears to be borrowed from physicians or other high-ranking employees in various fields. Carrying a pen pinned in one's breast pocket suggests superiority, authority, and power (interpretation step $1 \mathrm{~b}$ ).

The most eye-catching moment is "feigned fighting". In a show of fighting, one of the boys starts boxing another (usually in the arm). The other boy reciprocates, resulting in mutual boxing (interpretation step 1a). This mutual "exhibition or ensuring of masculinity, strength, and superiority" as elicited by the "feigned fighting" (interpretation Step 1b) is quite frequent. In the subgroups analyzed, this behavior is observed only in boys. Therefore, it is clearly a characteristic that constructs the male gender (interpretation step 2).

Another way to construct male gender (interpretation step 2) is assuring one another of one's own prowess and quality (interpretation Step $1 b$ ). This is done by imitating gestures (interpretation step 1a). This behavior is observed only in boys. In the overall group, a boy, usually one with considerable social capital, displays a gesture. The gesture is then imitated by one or more of the other boys and corroborated or confirmed by the rest of the subgroup with laughter or the like. This behavior pattern can be described as hegemonic masculinity. According to Budde [50] (p. 217), this represents a symbolic recognition of masculinity commonly observed in homosocial male groups. "[ ... ] hegemonic masculinity behavior patterns [ ... ] largely prevail unchallenged. Actors as defined in this pattern hardly need to legitimize their masculinity - they are rather sovereign, confident actors." [50] (p. 219).

Presenting one's symbolic and social capital also plays a major role with boys. A boy who turns out to be the leader of a subgroup clarifies his position several times, emphatically, vis-à-vis a marginalized boy who was also part of this subgroup. The demonstration of symbolic and social 
capital (interpretation step 1b) is particularly noticeable as the lack of attention paid to the marginalized boy (interpretation step 1a). The behavior shown is adopted by other male members of the group. Similar behavior is not observed in the girls. They work as a team and include all girls present at the table, although clear role assignments also become apparent among them.

\section{Discussion}

The results will be discussed with respect to potential approaches to experimental science teaching. Before we begin this discussion, it must be noted that the classification used here (i.e., man/woman, boy/girl) is the result of an interactive and socially conditioned process of attribution and construction. Our society thus adheres to a consolidated image of the process by which man and woman evolve into what they are. This image is generated by the gender socialization process through which everyone inevitably passes [26]. It must not be glossed over that this gender inequality has been engendered by tradition and is now the basis of our actions and thoughts. These traditional patterns are encouraged in particular by the institution of schools because this is the venue in which adequate behavior is learned, exemplified, and consolidated [26]. As already mentioned, these gender-typical patterns are highly persistent over time (i.e., they will not change much in the near future). Lorber [51] refers to a so-called "sameness taboo" (p. 26) emphasizing a requirement for intra-societal differences between men and women. As a member of this society, claiming to think and speak independently and freely within this binary categorization man-woman/boy-girl is therefore disingenuous. There is, however, a positive benefit of this categorization. One need not constantly question whether what one sees is what it appears to be. Categories help us weigh matters and make decisions quickly without having to reconsider every aspect. On the other hand, they may restrict and limit the unfettered development of the personality. To appropriately encourage and support young people, a number of the behavior patterns revealed in this study can be used to develop concrete proposals for classroom approaches.

(1) A gender-typical behavior pattern being observed is the selection of experimentation device, whereby (some) girls tend to select devices that resemble household appliances and (some) boys prefer more technical equipment. One possible didactic approach would be to provide only technical equipment to master an experimental task, thereby enabling girls to try out the more technical equipment. Biological content is suitable insofar as this field is of interest to both boys and girls [52] -it is not a scientific field that girls tend to reject [53] and can thus provide a bridge to use technical equipment. Another approach would be mixed-sex pairs with a clear division of responsibilities. Teachers can counteract certain tendencies based on a knowledge of certain properties, routine activities, and the "comfort zones" of the respective sexes. They should be aware that in the school setting, girls are confronted with the problem of working scientifically and at the same time being girly [54]. By considering this aspect, teachers can provide girls with tasks and material that focus on the scientific approach.

(2) In this study, activities reflecting a caring attitude were also identified as gender-typical characteristics occurring mainly in girls. To promote the adoption of social activities among boys as well, roles can be deliberately allocated within groups in order to move both boys and girls away from their favored areas of activity. For example, boys could be given the responsibility for handing out the materials in such a way that every group member has access to the materials. Likewise, boys could play an intermediary role by being asked to ensure that all group members are given the opportunity to become involved in the planning and implementation of an experiment.

(3) A male behavior pattern apparent in the present study was carrying a pen in one's breast pocket. It corresponds to the traditional image of the male researcher or authority, which is also conveyed by the media and is thus part of the background experience of the pupils. This pre-consolidated image of men as scientists and authorities [55] contributes to the subject-specific self-image of pupils in that it affects how the youths perceive themselves (i.e., whether or not they are competent) [56]. If research and knowledge (represented by the pen in the breast pocket) is considered male, this concept cannot be congruent with femininity in the eyes of female (and male) pupils. At this point, frequent mention of female researchers could encourage a positive subject-specific self-image in female pupils [57]. 
Both girls and boys benefit if a female researcher comes into class. However, it is important that the role model is seen as personable and engages students in practical science activities [58].

(4) In the present study, boys achieved mutual recognition of masculinity by paying particular attention to and imitating behavior that interrupted the lessons and could even be termed asocial (e.g., exclusion of a group member who did not meet the standard of masculinity). Supporting this hypothesis, one can cite Borg (2015) [59], who points out that while girls are more focused and meet the working targets at school, boys are more likely to interrupt lessons. These interruptions elicit criticism by teachers. This is reflected in the findings of Kreienbaum and Metz-Göckel [60], who noted that censure addressed to boys frequently addresses their social behavior, whereby praise usually addresses their performance; the reverse is true for girls. This form of feedback provides ongoing confirmation of traditional perspectives i.e., that performance levels are important for boys and social behavior is important for girls. To counteract this tradition, teachers should explicitly praise boys for adaptive social behavior (and girls for expertise).

(5) The behavior pattern "requesting" is not characteristic for either of the two sexes in this study, although it tends to be practiced more by girls. Among boys, only those with high levels of social and symbolic capital can allow themselves to make requests. Based on this insight, teachers can focus on presenting "requesting" behavior as explicitly positive. They can also specifically address male students with low levels of social capital to see whether there are requests to be made and then characterize these requests in positive terms as an active way of following the lesson.

(6) The behavior pattern "rearranging one's hair" does not actively influence the course of the lesson as does, for example, "feigned boxing". However, it may also represent a distraction. One way to counter this pattern would be to establish a clear rule that in experimental classes, hair must be tied back and loose hair strands should be fixed by hair clips. Because hairstyles change over time and boys may also sport long hair, this rule should be applied to both sexes.

Knowledge of gender-typical behavior patterns can also produce concrete benefits for teachers. The boys in this study drew attention to themselves by "feigned boxing", thereby eliciting censure from the teachers. These "fights for show" usually represent a behavior strategy that aims at asserting one's masculinity and not specifically disturbing the lesson because of poor didactic materials, inappropriate teaching style, or a boring lesson topic. This knowledge can allow the teacher to deal differently with the interruption. The teacher would then stop assuming the disturbance is directed at him or her and thus experience emotional relief and possibly a lower level of stress [61]. The Potsdam teacher study, for example, shows how important this kind of stress reduction can be. This shows that the behavior of difficult students is perceived as one of the most stressful factors experienced in teaching [62].

In summary, the results of this study may serve to sensitize teachers to possible gender construction strategies of male and female pupils. Because of their general nature, several strategies are assumed to occur not only in experimental group activities in biology lessons but also in the other natural sciences and even in other subjects. The approaches proposed in the discussion could help minimize gender-typical behavior and ensure more harmonious lessons. Likewise, an emotional release of the teacher can be achieved; this would be beneficial to teachers as well as their male and female pupils. Of course, it is important not to regard the proposals for action listed here as absolute in any sense. There are girls who are dominant, technically adept, and/or less predisposed to caring behavior. Similarly, there are boys with more feminine attributes. The actions of the teacher must therefore take into account the particular temperament of the male/female student. Generalized approaches will fail to do justice to the individual pupil.

Author Contributions: Conceptualization, D.L., K.S.; Methodology, D.L., K.K.; Validation, D.L.; Investigation, K.K.; Resources, K.S.; Writing-Original Draft Preparation, K.K.; Writing-Review \& Editing, K.S.; Visualization, K.K.; Supervision, K.S.; Funding Acquisition, K.S., D.L.

Funding: This research received no external funding.

Acknowledgments: We are grateful for the support by the Faculty of Mathematics and Natural Sciences of the University of Cologne who provided funding for gender-related projects. We sincerely thank the students of the 
Hildegard-von-Bingen-Gymnasium in Cologne for taking part in our study as well as the head of the school, and the teacher responsible for the group of students for cooperating with us. We would also like to thank the candidate teacher students who worked as tutors in the inquiry course and the student assistant who did the videotaping.

Conflicts of Interest: The authors declare no conflict of interest.

\section{References}

1. Germann, P.J.; Aram, R.; Burke, G. Identifying patterns and relationships among the responses of seventh-grade students to the science process skill of designing experiments. J. Res. Sci. Teach. 1996, 33, 79-99. [CrossRef]

2. National Research Council. A Framework for K-12 Science Education: Practices, Crosscutting Concepts, and Core Ideas; The National Academies Press: Washington, DC, USA, 2012; ISBN 978-0-309-21742-2.

3. Asay, L.D.; Orgill, M. Analysis of essential features of inquiry found in articles published in the science teacher, 1998-2007. J. Sci. Teach. Educ. 2010, 21, 57-79. [CrossRef]

4. Wellnitz, N.; Mayer, J. Erkenntnismethoden in der Biologie-Entwicklung und Evaluation eines Kompetenzmodells. Zeitschrift Didaktik der Naturwissenschaften 2013, 19, 315-345.

5. Capps, D.K.; Crawford, B.A.; Constas, M.A. A review of empirical literature on inquiry professional development: Alignment with best practices and a critique of the findings. J. Sci. Teach. Educ. 2012, 23, 291-318. [CrossRef]

6. National Research Council. Inquiry and the National Science Education Standards: A Guide for Teaching and Learning; The National Academies Press: Washington, DC, USA, 2000; ISBN 978-0-309-06476-7.

7. Anderson, R.D. Reforming science teaching: What research says about inquiry. J. Sci. Teach. Educ. 2002, 13, 1-12. [CrossRef]

8. Minner, D.D.; Levy, A.J.; Century, J. Inquiry-based science instruction-What is it and does it matter? Results from a research synthesis years 1984 to 2002. J. Res. Sci. Teach. 2010, 47, 474-496. [CrossRef]

9. Rönnebeck, S.; Bernholt, S.; Ropohl, M. Searching for a common ground-A literature review of empirical research on scientific inquiry activities. Stud. Sci. Educ. 2016, 52, 161-197. [CrossRef]

10. Abd-El-Khalick, F.; BouJaoude, S.; Duschl, R.; Lederman, N.G.; Mamlok-Naaman, R.; Hofstein, A.; Niaz, M.; Treagust, D.; Tuan, H.L. Inquiry in science education: international perspectives. Sci. Educ. 2004, 88, 397-419. [CrossRef]

11. European Commission. Science Education Now: A Renewed Pedagogy for the Future of Europe; Office for Official Publications of the European Communitie: Luxembourg, 2007; Available online: https://ec.europa.eu/ research/science-society/document_library/pdf_06/report-rocard-on-science-education_en.pdf (accessed on 23 June 2018).

12. Dawson, C. Upper primary boys' and girls' interests in science: have they changed since 1980? Int. J. Sci. Educ. 2000, 22, 557-570. [CrossRef]

13. Harwell, S.H. In their own voices: Middle level girls' perceptions of teaching and learning science. J. Sci. Teach. Educ. 2000, 11, 221-242. [CrossRef]

14. Baker, D.; Leary, R. Letting girls speak out about science. J. Res. Sci. Teach. 1995, 32, 3-27. [CrossRef]

15. Jones, M.G.; Howe, A.; Rua, M.J. Gender differences in students' experiences, interests, and attitudes toward science and scientists. Sci. Educ. 2000, 84, 180-192. [CrossRef]

16. Taber, K.S. Gender differences in science preferences on starting secondary school. Res. Sci. Technol. Educ. 1991, 9, 245-251. [CrossRef]

17. Uitto, A. Interest, attitudes and self-efficacy beliefs explaining upper-secondary school students'orientation towards biology-related careers. Int. J. Sci. Math. Educ. 2014, 12, 1425-1444. [CrossRef]

18. Osborne, J.; Simon, S.; Collins, S. Attitudes towards science: A review of the literature and its implications. Int. J. Sci. Educ. 2003, 25, 1049-1079. [CrossRef]

19. Damarin, S.; Erchick, D.B. Toward clarifying the meanings of "gender" in mathematics education research. J. Res. Math. Educ. 2010, 41, 310-323.

20. Pryzgoda, J.; Chrisler, J.C. Definitions of gender and sex: the subtleties of meaning. Sex Roles 2000, 43, 553-569. [CrossRef]

21. Torgrimson, B.N.; Minson, C.T. Sex and gender: What is the difference? J. Appl. Psychol. 2005, 9, $785-787$. [CrossRef] [PubMed]

22. West, C.; Zimmerman, D.H. Doing gender. Gend. Soc. 1987, 1, 125-151. [CrossRef] 
23. Sabbe, E.; Aelterman, A. Gender in teaching: A literature review. Teach. Teach. 2007, 13, 521-538. [CrossRef]

24. Deutsch, F.M. Undoing gender. Gend. Soc. 2007, 21, 106-127. [CrossRef]

25. Gildenmeister, R. Doing Gender: Soziale Praktiken der Geschlechterunterscheidung [Doing Gender: Social Practice of Gender Differentiation]. In Handbuch Frauen-und Geschlechterforschung: Theorie, Methoden, Empirie [Manual of Research on Women and Gender: Theory, Methods, Empiricis], 2nd ed.; Becker, R., Kortendiek, B., Eds.; SV Verlag für Sozialwissenschaften: Wiesbaden, Germany, 2008; pp. 137-145, ISBN 978-3-531-16154-9.

26. Auhadeeva, L.A.; Yarmakeev, I.E.; Aukhadeev, A.E. Gender competence of the modern teacher. Int. Educ. Stud. 2015, 8, 32-37. [CrossRef]

27. Bailey, L.E.; Graves, K. Gender and education. Rev. Res. Educ. 2016, 40, 682-722. [CrossRef]

28. Brotman, J.S.; Moore, F.M. Girls and science: A review of four themes in the science education literature. J. Res. Sci. Teach. 2008, 45, 971-1002. [CrossRef]

29. Scantlebury, K. Still part of the conversation: Gender issues in science education. In Second International Handbook of Science Education; Fraser, B., Tobin, K., McRobbie, C.J., Eds.; Springer: Dordrecht, The Netherlands, 2012; pp. 499-512, ISBN 978-1-4020-9040-0.

30. Kenway, J.; Gough, A. Gender and science education in schools: A review 'with attitude'. Stud. Sci. Educ. 1998, 31, 1-29. [CrossRef]

31. Sinnes, A. Three approaches to gender equity in science education. Nord. Stud. Sci. Educ. 2006, 2, 72-83. [CrossRef]

32. Francis, B.; Paechter, C. The problem of gender categorisation: addressing dilemmas past and present in gender and education research. Gend. Educ. 2015, 27, 776-790. [CrossRef]

33. Kerkhoven, A.H.; Russo, P.; Land-Zandstra, A.M.; Saxena, A.; Rodenburg, F.J. Gender stereotypes in science education resources: a visual content analysis. PLoS ONE 2016, 11. [CrossRef] [PubMed]

34. Chilisa, B. Towards Equity in Assessment: Crafting gender-fair assessment. Assess. Educ. Princ. Policy Pract. 2000, 7, 61-81. [CrossRef]

35. Sjøberg, S.; Schreiner, C. The ROSE Project: An Overview and Key Findings. 2010. Available online: http:/ / www.cemf.ca/\%5C/PDFs/SjobergSchreinerOverview2010.pdf (accessed on 23 June 2018).

36. Farland-Smith, D.; Finson, K.D.; Arquette, C.M. How Picture Books on the National Science Teacher's Association Recommend List Portray Scientists. Sch. Sci. Math. 2017, 117, 250-258. [CrossRef]

37. Altermatt, E.R.; Jovanovic, J.; Perry, M. Bias or responsivity? Sex and achievement-level effects on teachers' classroom questioning practices. J. Educ. Psychol. 1998, 90, 516-527. [CrossRef]

38. Pilcher, J.; Whelehan, I. Key Concepts in Gender Studies; SAGE Publications: London, UK, 2004; ISBN 0-7619-7035-5.

39. Faulstich-Wieland, H.; Horstkemper, M. Schule und Genderforschung [School and gender research]. In Handbuch Geschlechterforschung und Fachdidaktik [Manual of Gender Research and Subject Didactics]; Kampshoff, M., Wiepcke, C., Eds.; VS Verlag für Sozialwissenschaften: Wiesbaden, Germany, 2012; pp. 25-38, ISBN 978-3-531-18222-3.

40. Faulstich-Wieland, H. Mädchen und Naturwissenschaften in der Schule. Expertise für das Landesinstitut für Lehrerbildung und Schulentwicklung Hamburg [Girls and the Natural Sciences in School. Expert Report for the State Institute for Teacher Education and School Development, Hamburg]; Fachbereich Erziehungswissenschaft der Universität Hamburg: Hamburg, Germany, 2004; Available online: http:/ / sinus-transfer.uni-bayreuth.de/ fileadmin/MaterialienBT/Expertise.pdf (accessed on 23 June 2018).

41. Schlüter, K. Umgang mit der Genderproblematik im mathematisch-naturwissenschaftlichen Unterricht [Approaches to gender problems in maths and science teaching]. Beiträge zur Lehrerinnen- und Lehrerbildung [Contributions to teacher education] 2001, 19, 401-412.

42. Höblich, D. Biografie, Schule und Geschlecht. Bildungschancen von SchülerInnen [Biography, School and Gender. Pupils' Educational Opportunities]; VS Verlag für Sozialwissenschaften: Wiesbaden, Germany, 2010; ISBN 978-3-531-92272-0.

43. Reiss, M.J. Gender issues in science lessons as revealed by a longitudinal study. In Proceedings of the British Educational Research Association Conference, Cardiff, UK, 7-10 September 2000; Available online: http:/ / www.leeds.ac.uk/educol/documents/00001599.htm (accessed on 23 June 2018).

44. Wang, L.-C. Mainstreaming Gender into Schools in the Taiwan Context. Chin. Educ. Soc. 2014, 47, $23-31$.

45. Bohnsack, R. The interpretation of pictures and the documentary method. In Qualitative Analysis and Documentary Method in International Educational Research; Bohnsack, R., Pfaff, N., Weller, W., Eds.; B. Budrich: Opladen, Germany, 2010; pp. 267-292, ISBN 978-3-86649-236-3. 
46. Bohnsack, R. Die dokumentarische Methode in der Bild- und Fotointerpretation [The documentary method in image and photo interpretation]. In Die dokumentarische Methode und ihre Forschungspraxis. Grundlagen qualitativer Sozialforschung [The Documentary Method and Its Practice in Research. Fundamentals of Qualitative Ssocial Research], 3rd ed.; Bohnsack, R., Nentwig-Gesemann, I., Nohl, A.-M., Eds.; VS Verlag für Sozialwissenschaften: Wiesbaden, Germany, 2013; pp. 75-98.

47. Stohs, J.H. "Doing gender" and conflicts over the household division of labor. In Proceedings of the Annual Scientific Meeting of the Gerontological Society of America, San Francisco, CA, USA, 22-26 November 1991.

48. Häussler, P.; Hoffman, L.; Langeheine, R.; Rost, J.; Sievers, K. A typology of students' interest in physics and the distribution of gender and age within each type. Int. J. Sci. Educ. 1998, 20, 223-238. [CrossRef]

49. Meise, S. Organisation und Vielfalt: Modernisierungen der Gewerkschaftspraxis [Organization and Diversity: Modernizations in Trade Union Practice]; Springer-Verlag: Wiesbaden, Germany, 2014; ISBN 3658060581.

50. Budde, J. Inklusion und Exklusion. Zentrale Mechanismen zur Herstellung von Männlichkeit zwischen Schülern [Inclusion and exclusion. Central mechanisms of masculinity construction amongst pupils]. In FrauenMännerGeschlechterforschung: State of the Art [Women Men Gender Research. State of the Art]; Aulenbach, B., Bereswill, M., Löw, M., Meusel, M., Mordt, G., Schäfer, R., Scholz, S., Eds.; Westfälisches Dampfboot: Münster, Germany, 2006; pp. 217-227, ISBN 978-3-89691-220-6.

51. Lorber, J. "Night to his day": The social construction of gender. In Paradoxes of Gender; Lorber, J., Ed.; Yale University Press: New Haven, CT, USA, 1994; pp. 13-36, ISBN 0300064977.

52. Mavrikaki, E.; Koumparou, H.; Kyriakoudi, M.; Papacharalampous, I.; Trimandili, M. Greek Secondary School Students' Views about Biology. Int. J. Environ. Sci. Educ. 2012, 7, 217-232.

53. Jahnke-Klein, S. Benötigen wir eine geschlechtsspezifische Pädagogik in den MINT-Fächern? Ein Überblick über die Debatte und den Forschungsstand [Do we need a gender-specific pedagogy in the MINT-subjects? A summary of the debate and the state of research]. Schulpädagogik-Heute 2013, 4, 46-68.

54. Carlone, H.B.; Johnson, A.; Scott, C.M. Agency amidst formidable structures: How girls perform gender in science class. J. Res. Sci. Teach. 2015, 52, 474-488. [CrossRef]

55. Finson, K.D. Drawing a scientist: what we do and do not know after fifty years of drawings. Sch. Sci. Math. 2002, 102, 335-345. [CrossRef]

56. Lembens, A.; Bartosch, I. Genderforschung in der Chemie- und Physikdidaktik [Gender research in chemistry and physics didactics]. In Handbuch Geschlechterforschung und Fachdidaktik [Manual of Gender Research and Subject Didactics]; Kampshoff, M., Wiepcke, C., Eds.; VS Verlag für Sozialwissenschaften: Wiesbaden, Germany, 2012; pp. 83-98.

57. Palm, K. Grundlagen und Visionen einer genderreflexiven Biologiedidaktik [Fundamentals and visions of gender-responsive biology didactics]. In Handbuch Geschlechterforschung und Fachdidaktik [Manual of Gender Research and Subject Didactics]; Kampshoff, M., Wiepcke, C., Eds.; VS Verlag für Sozialwissenschaften: Wiesbaden, Germany, 2012; pp. 69-82, ISBN 978-3-531-18222-3.

58. Conner, L.D.C.; Danielson, J. Scientist role models in the classroom: How important is gender matching? Int. J. Sci. Educ. 2016, 38, 2414-2430. [CrossRef]

59. Borg, E. Classroom behaviour and academic achievement: How classroom behaviour categories relate to gender and academic performance. Br. J. Sociol. Educ. 2015, 36, 1127-1148. [CrossRef]

60. Kreienbaum, M.A.; Metz-Göckel, S. Koedukation und Technikkompetenz von Mädchen: Der heimliche Lehrplan der Geschlechtererziehung und wie man ihn ändert [Coeducation and Technical Competence of Girls. The Secret Didactic Agenda of Gender Education and How to Change It]; Juventa-Verlag: Weinheim, Germany, 1992; ISBN 3779908395.

61. Krause, A.; Dorsemagen, C.; Baeriswyl, S. Zur Arbeitssituation von Lehrerinnen und Lehrern: Ein Einstieg in die Lehrerbelastungs- und -gesundheitsforschung [On the job situation of teachers: Introduction to research on teacher stress exposure and health research]. In Belastung und Beanspruchung im Lehrerberuf [Stress and Workload in the Teaching Profession. Models Findings Interventions], 2nd ed.; Rothland, M., Ed.; Springer VS: Wiesbaden, Germany, 2013; pp. 61-80, ISBN 978-3-531-18246-9.

62. Schaarschmidt, U. Halbtagsjobber? Psychische Gesundheit im Lehrerberuf [Part-Time Job? Mental Health in the Teaching Profession-Analysis of a Situation That Demands Change], 2nd ed.; Beltz: Weinheim, Germany, 2005.

(C) 2018 by the authors. Licensee MDPI, Basel, Switzerland. This article is an open access article distributed under the terms and conditions of the Creative Commons Attribution (CC BY) license (http:/ / creativecommons.org/licenses/by/4.0/). 